\title{
To post or not to post? Exploring the motivations behind brand-related engagement types on social networking sites
}

\section{Purpose:}

This study investigates consumer motivations behind brand-related engagement on social media by exploring three different engagement types: consuming, contributing (to), and creating. Previous research suggests that many brands seek to engage with consumers via communications on social networking sites, however, most focus on quantitative metrics and measurement tools to evaluate such behaviour and so offer limited understanding and guidance. To address this gap the current study utilises a mixed-method approach to investigates the motivations behind each brand-related engagement type to provide deeper insight into what motivates consumers to engage with brand-related posts on social networking sites. This study also aims to investigate the motivations between different engagement types exist, and whether these vary between brands and other people's brandrelated posts.

Design: A two-phase integrated qualitative-quantitative research design was utilised. Twelve semi-structured interviews explored the range of consumers' brand engagement motivations before an online survey $(\mathrm{N}=225)$ identified and confirmed the motivational similarities and differences between the three brand-related engagement types.

Findings: Different motives influence each brand-related engagement type, bar the 'enjoyment' motive which triggers all three engagement types. Of particular interest is the identification of a new motive for engagement - seeking compensation - that influences negative brand-related engagement.

Practical implications: Through understanding what motivates consumers to consume, contribute, and create, brands can tailor their marketing messages to each different brand- 
related engagement type. This will increase their engagement with consumers on social networking sites, as specific segments can be created by the brand to enhance their targeting strategies based on consumers' differing motivations within social media channels.

Originality/value: This study contributes a much-needed framework of motivations for brand-related engagement on social media, recognising variations in motivations by type of engagement (consume; contribute (to); create).

Keywords: Motivations, brand-related engagement types, social networking sites, brandrelated content.

Article Classification: Research Paper

\section{To post or not to post? Exploring the motivations behind brand-related engagement on social networking sites}

\section{Introduction:}

Understanding consumers' brand-related activities on social networking sites is a continuing challenge for social media marketers, brand managers, and marketing executives, and is increasingly considered in brands' social media marketing strategies (e.g., Cruz et al., 2017). However, whilst social media analytical tools allow brands to measure consumers' brand-related activities, these provide insufficient guidance. The focus on just measuring quantitative data e.g., numbers of comments, likes, tweets, etc. does not allow for brands to explore and understand the reasons behind why consumers engage with them on social media and what motivations lie behind each type of brand engagement. 
Over recent years the popularity of the Internet has led to tremendous growth in the use of social media with the number of active social media users worldwide growing $8.7 \%$ over the past year, to reach 3.81 billion people in 2020 (We Are Social, 2020), a number projected to increase to almost 4.41 billion by 2025 (Statista, 2020a). Globally, individuals spend an average of 144 minutes per day on social networking platforms (Statista, 2020b) sharing photos, tweets, posts, videos, etc. which have helped the rise of popular social networking sites such as Facebook, YouTube, Twitter, and Instagram. It has been brought to brands' attention that consumers use social media not only to create individual content but also to engage with brand-related posts. Consumers regularly use search engines to find relevant online reviews (Kumar et al., 2005) and social media posts to aid purchase decisions, and in return, social networking sites help them to share their brand-related opinions with others, which may in turn influence these 'others' purchase decisions.

Therefore, social media platforms are seen as essential outlets for consumers and brands as they provide great opportunities for users, as well as consumers, to create content regarding brands (Muntinga et al., 2011; Piehler et al., 2019) and their offering.

The consumer-brand relationship conversation has moved from traditional communication channels to social networking sites, leading scholars to focus on the concepts that predict the dynamics of interactive consumer-brand relationships (e.g., Bolton and Saxena-Iyer, 2009; Dholakia et al., 2004; Malthouse and Hofacker, 2010; Shao, 2009) as well as consumer-toconsumer brand-related interactions on social media. Early investigations provide some initial understanding behind consumer engagement on online platforms but also present some shortcomings and gaps to be filled. Firstly, these studies were undertaken a decade or more ago and do not review recent technological changes within social media, particularly its creative features which have an impact on consumer engagement (Baldus et al., 2015; Kabadayi and Price, 2014). Secondly, whilst several studies have investigated consumer 
engagement in general with regards to online brand communities (Baldus et al., 2015), social media engagement (Park et al., 2009) and brand channels (Hollebeek et al., 2014), very few have examined social media brand-related engagement (e.g., Dolan et al., 2016; Dolan et al., 2017; Dolan et al., 2019; Muntinga et al., 2011). Third, Sashi (2012) identified a need to further explain motivations behind different social media engagement related to brands in response to current marketing and advertising practices within social media. Finally, Dolan et al. (2019) state that studies exploring consumer engagement with social media are only just beginning to emerge and hence call for a theoretical understanding of the nature of engagement behaviour within a social media context to be developed.

The current study responds to these calls and addresses these research gaps through; 1) gaining further insight into the motivations behind brand-related engagement types on social networking sites; 2) identifying the salient motivations in consumers' active (creating and contributing) and passive (consuming) brand-related engagement behaviour with brandrelated content created by both brands and other people; and 3) ascertaining if any similarities/differences in motivations between different engagement types exist and whether these vary between brands and other people's brand-related posts. To do this, firstly the literature on consumer engagement concerning usage types is reviewed, followed by a discussion of the key motivations behind brand-related engagement posts created by both brands and other consumers on social networking sites (i.e., Facebook and Twitter). Then utilizing Uses and Gratifications (U\&G) theory (Katz and Foulkes, 1962) and SelfDetermination Theory (SDT), this paper explains how specific motivations may influence consumers to engage passively or actively with brand-related posts through consuming, contributing, and creating. Within this paper consumer engagement with brand-related posts created by brands as well as other people on social media is examined, enabling the development of a conceptual framework that draws upon the theoretical foundations of Uses 
and Gratifications (U\&G) theory, SDT, and consumer engagement literature to develop a categorisation of motivations in relation to three different engagement types. Finally, the theoretical and practical implications for management are presented along with limitations of the research and avenues for further research.

\section{Literature Review}

\subsection{Consumer Usage Types and Engagement}

Social media sites are frequented by Internet users for different purposes, including engaging with brand-related posts. In turn, brands have increased their investment in brand communities on social media (Baldus et al., 2015), as well as social media marketing, to enhance communication with their consumers. Consequently, key topics relating to engagement have gained increasing attention from scholars. Resulting studies have investigated a wide range of related topics including consumer engagement (Brodie et al., 2013), online engagement (Calder et al., 2009; Thakur, 2018), and brand community engagement on social media (Algesheimer et al., 2005; Baldus et al., 2015).

van Doorn et al (2010, p.263) identified that consumer engagement behaviours can "provide a useful framework for classifying and segmenting customers, based on their propensity to engage and the types of engagement behaviours they display". Reflecting this, a number of researchers have focused on usage behaviours to help understand and classify different consumer engagement types on social media sites (e.g., Chu and Kim, 2011; Heinonen, 2011; Muntinga et al., 2011; Shao, 2009; Triantafillidou and Siomkos, 2018).

Firstly, consumer-to-consumer brand-related engagement (eWOM) on social networking sites has been investigated through categorising consumers into three different usage types: Opinion seeking (Flynn et al., 1996); Opinion passing (Dellarocas, 2003; Norman and Russell, 2006); and Opinion giving (Chu and Kim, 2011; Feick and Price, 1987). 
Indifference to this, Shao (2009) focused on identifying the activities of social media users and proposed three types in his user-generated typology, namely: 1) Consuming; 2) Participating; and, 3) Producing. Whilst this model aims to understand individuals' engagement with user-generated media (UGM), it focuses on individuals' general online engagement with any content, not specifically brand-related content.

Taking the social media usage typology concept further, Muntinga et al.(2011) explored users' brand-related social media use resulting in a motivation framework based on a continuum from high to the low brand-related activity of consumers' online brand-related activities (COBRA). The continuum recognises the extent to which the degree of engagement varies in level of intensity (Dolan et al., 2016) from passive forms of engagement (e.g., "liking" a Facebook brand page or post,) to active forms which relate to customer participation in co-creation activities (e.g., writing comments about a brand on Twitter) (Malthouse et al., 2013; Muntinga et al., 2011). From this Muntinga et al. (2011) identify three types of brand engagement, namely consuming (passive), contributing (active), and creating (active). Indifference, Tsai and Men (2013) and Triantafillidou and Siomkos (2018) suggest two user categories in their studies of consumer brand engagement on Facebook: consuming and contributing.

Given the limited research undertaken on the motivations behind brand-related engagement on social networking sites, this research focuses on three aspects of usage behaviour - consuming, contributing, and creating - so as not to miss any nuances that may occur if only two categories were investigated. These categories are outlined in Table I, then discussed in turn. 
Table I. COBRA typology of three usage types - consuming, contributing, and creating

\begin{tabular}{ll}
\hline Engagement type & Examples of brand-related engagement on social media use \\
\hline Consuming & - Viewing brand-related videos \\
- & Listening to brand-related audio \\
- & Viewing brand-related pictures \\
- & Reading comments on brand profiles on social network sites \\
- & Reading product reviews \\
- Viewing brand/product related tweets/posts \\
- Liking products and/or brands \\
- Joining a brand profile on a social network site \\
- Engaging in branded conversations, e.g., on online brand \\
Contributing \\
- community forums or social network sites \\
- Clicking brands' ads \\
- Commenting on brand-related weblogs, video, audio, pictures, etc. \\
- conversations \\
- Publishing brand-related posts/tweets \\
- Writing brand-related articles \\
Creating
\end{tabular}

Adapted from: Dolan et al. (2019); Li and Bernoff (2008); Muntinga et al. (2011); Shao (2009), Schivinski et al. (2016).

\subsubsection{Consuming Brand-related Content}

Consuming is classified as social media usage of people who only read brand- and product-related posts that companies or other people have created, including videos, posted ratings, and reviews (Muntinga et al., 2011). This engagement type has been recognised as a form of passive engagement where users demonstrate a minimum level of positive engagement to consume content on social media (Dolan et al., 2019). Often, it has also been 
described by online advertisers as 'reach' or impressions in an advertising context (Buzeta et al., 2020).

\subsubsection{Contributing to Brand-related Content}

On a continuum, contributing behaviour deficits the middle level of online brand activities of consumers (Muntinga et al., 2011). It signifies users' interactions with brand-related content from both brands and other users and includes liking, commenting, retweeting, quoteretweeting, as well as favouriting brands and other people's activities and content on social media. This engagement has mostly been provoked by online advertisers to receive active engagement from social media users (Buzeta et al., 2020). The liking and commenting functions on Facebook and the retweet, favourite, and quote-retweet functions on Twitter enable anyone to easily respond to and engage with existing brand posts (Dolan et al., 2019; Kabadayi and Price, 2014) rather than requiring them to create their post.

\subsubsection{Creating Brand-related Content}

Creating behaviour is where "users initiate unprompted, positive, and active contributions to social media communities" (Dolan et al., 2019, p.2217) It acknowledges that many people create and publish their content (e.g., videos, pictures, blogs, personal home pages) on online platforms (Shao, 2009) that has a positive impact on purchase decisions (Mishra, 2019). Indeed, the number of video content hours uploaded every 60 seconds on YouTube has grown exponentially and reached 500 hours (YouTube.com, 2020) whilst Facebook sees 147,000 photos uploaded and 54,000 links shared every 60 seconds (Omnicore, 2019). Furthermore, social media has provided innovative ways of creating content for consumers on their product and brand experiences. 
The sample for the current study includes consumers who represent a mix of all three usage types classified as 1) those who only consume brand-related posts, tweets, and pictures created by consumers and brands; 2) those displaying contributing activities such as liking, favouriting, retweeting, quote-retweeting and commenting on brands and other people's brand-related posts on social media; 3) consumers who create their brand-related content such as posting photos, Facebook posts, and tweets (e.g., Muntinga et al., 2011).

\subsection{Motivations and Brand-related Engagement}

Customer engagement behaviour can be defined as "the customers' behavioural manifestation toward a brand or firm, beyond purchase, resulting from motivational drivers" (van Doorn et al., 2010, p.253). Hennig-Thurau et al. (2004) state motivations are the predictors of consumers' brand-related engagement behaviour on social networking sites, and with the increased importance of online engagement, a number of studies have explored consumers' motivations for online brand-related posts (e.g., Cheung and Lee, 2012; Moldovan et al., 2011; Shao, 2009). Previous research has found that motives affect brandrelated activities on social media (De Vries et al., 2017; Hollebeek and Macky, 2019) and past studies identify brand-related engagement in different contexts explaining the motives behind spreading brand-related posts via online forums (Cheung and Lee, 2012), online platforms (Hennig-Thurau et al., 2004), online communities (Baldus et al., 2015; Brodie, 2011; Brodie, 2013) and social media sites (Muntinga et al., 2011). Consumers intend to engage with brand-related posts via online forums as they are triggered by the need for building a reputation, helping others, and a sense of belonging (Cheung and Lee, 2012).

Scholars have considered several motivations to specifically explain consumers' online brand-related activities. Enveloping several concepts of eWOM, user-generated content (UGC), and typologies of consumer behaviour in a computer-mediated environment, 
Muntinga et al. (2011) investigated consumers' different brand activities on social media (cf. Rodgers et al., 2007). Adapting Uses and Gratifications (U\&G) theory, as well as previous eWOM motivation literature, their work investigates consumers' motivations in order to explore consumers' general brand-related activities on social media. They found consumers who consume brand-related posts on social media are driven by the motive of informationseeking, while entertainment, remuneration (e.g., reward), personal identity, social interaction, and entertainment motives drive consumers to contribute to brand-related posts on social media. The creation of brand-related posts on social media is driven by personal identity, social interaction, empowerment, and entertainment motives. Consequently, Muntinga et al. (2011) postulate an overview of consumers' online brand-related activities and motivations which provides a starting point for the current study. However, they do not investigate the motives behind different types of brand-related engagement (consume, contribute, create), or provide separate motivation frameworks to investigate consumers' engagement with i) brands and ii) other people's brand-related posts on social media to explore if they are driven by similar or different motives. The current study aims to address this gap by drawing upon the theoretical foundations of UGT and SDT to explore the different motivations that trigger users to engage with brand-related posts at different levels (types) of intensity on social media (e.g., Dolan et al., 2016) and study consumers' general brand-related engagement with posts from both brands and other people.

\subsection{Motivations for Brand-related Engagement on Social Networking Sites}

Researchers have proposed a variety of motivations that lie behind consumers' brandrelated engagement on social networking sites. These are now discussed briefly in turn and summarised in Table II. 


\subsubsection{Enjoyment}

The Enjoyment motive is also a part of the hedonic reward that in the context of brandengagement behaviour refers to entertainment, fun, and amusement (Yoo and Gretzel, 2008), the friendly environment that individuals experience as a result of joining brand communities on social media (Baldus et al., 2015), and the pleasure they have when they engage with brand-related posts on social networking sites. Online communities enable consumers not only to exchange product knowledge and experiences (Hung and Li, 2007; Ma and Agarwal, 2007; Pitta and Fowler, 2005) but also to have socially interactive enjoyable activities with others (Chan and Li, 2010; Schindler and Bickart, 2005) through engaging with brand-related posts from other people as well as brands.

\subsubsection{Information-seeking}

Information-seeking as motivation is identified in several studies (e.g., Muntinga et al., 2011; Park et al., 2009; Segev et al., 2012), and relates to information-related media gratifications. In the social media motivation literature, it includes opinion and adviceseeking (Kaye, 2007; Wang and Fesenmaier, 2003), information exchange (Ridings and Gefen, 2004), voyeurism (Bumgarner, 2007), and surveillance (Courtois et al., 2009) as well as risk reduction and surveying events taking place in society (Muntinga et al, 2011).

For social media, Muntinga et al.(2011) divided it into four sub-motivations: 1) prepurchase - reading brand-related content such as product reviews, comments, and brands/organisations' posts to make an appropriate purchase decision (Cvijikj and Michahelles, 2013; De Vries et al., 2012); 2) surveillance - observing and keeping up to date with one's social media environment or the brands' social media pages; 3) knowledge consuming other people's brand-related posts to receive information regarding a brand (Muntinga et al., 2011), as well as receiving new information from which benefits can be gained (Wirtz et al., 2013); and, 4) inspiration - the motivation that consumers have to 
consume brand-related information to acquire new ideas as a source of inspiration (Muntinga et al., 2011) e.g., new recipes. This study investigates the four sub-motivations of prepurchase, surveillance, knowledge, and inspiration.

\subsubsection{Altruism}

Altruism is closely related to the 'concern for others' (Hennig-Thurau et al., 2004), and can be either positive or negative (De Angelis et al., 2012). Negative altruism refers to a concern for others likened to 'other involvement' (Dichter, 1996), whilst positive altruism relates to helping others without anticipating a reward in return (Sundaram et al., 1998). It is applicable to social networking platforms, in terms of consumers sharing and spreading the message, to assist or protect their acquaintances, close relations, and for whomever, the consumer has a concern. For example, it can occur through eWOM engagement (Sundaram et al., 1998) such as helping consumers when making buying decisions or enabling them to protect themselves from making incorrect purchasing decisions (Hennig-Thurau et al., 2004). This study proposes to explore this motivation in its divided form of negative and positive altruism.

\subsubsection{Empowerment}

Consumers have always had power over companies in terms of their demand for goods or services (Kotler et al., 2019), as consumers can ignore, resist, adapt and control their own choices and these choices alone are a form of empowerment (Denegri-Knott et al., 2006). Although empowerment is explored in the management literature (e.g., Menon, 2001), consumer empowerment to evaluate consumers' eWOM engagement remains unexplored.

Empowerment is a motive that facilitates all three brand-related engagement types including consuming, contributing, and creating (Saridakis et al., 2016). For this research, empowerment is divided into negative and positive empowerment, dependent on how consumers use the power they have gained from social networking sites. While negative 
empowerment refers to the desire to engage with negative brand-related posts by using social media to embarrass the brand, positive empowerment stands for the desire of the consumer to be a brand ambassador, as they are connecting with brands through brand-related engagement on social networking sites.

\subsubsection{Reward}

Individuals who are extrinsically motivated usually behave in such a way as to receive a reward or praise from others, whilst an individual's behaviour driven by intrinsic motives is performed to experience the enjoyment and interesting aspects of the activity (Chatzisarantis and Biddle, 1998; Kowal and Fortier, 1999). Hence, it follows that individuals' brand-related engagement can be driven by the desire to receive an external reward (Hennig-Thurau et al., 2004; Muntinga et al., 2011) e.g., coupons, likes, retweets from brands, etc. through engaging with brand-related posts to develop their need for satisfaction.

The economic reward has been considered as an extrinsic motivation (e.g., Ryan and Deci, 2000; Tang et al., 2016). Prior studies found that economic reward has a significant effect on information sharing (Lee et al., 2015; Lin and Huang, 2013) and intention to contribute social commerce information (Wang, Li, and Spencer, 2019). However, Bock et al. (2005) advocated that extrinsic reward has a negative effect on information sharing, whilst Tang et al.(2016) indicated that external reward has a significant impact on the intention to share mobile coupons on social networking sites (SNSs).

\subsubsection{Seeking compensation}

Past studies have contributed to the 'theory of distributive justice', which explores the effect of satisfaction through compensation (Mattila and Patterson, 2004; Smith et al., 1999). The theory's purpose is to explain an individual's attitude when they seek fair distribution outcomes towards unfair exchange situations. Compensation can be categorised as either 
redress or reimbursement (Hocutt et al., 2006; Mount and Mattila, 2000), and different circumstances can cause customers to receive compensation (Estelami, 2000). Remuneration brands offer may be in the form of a cash refund, free products, or discount (Gelbrich and Roschk, 2011).

In this research, the complaint is considered as a motive that influences consumers' brandrelated engagement on social networking sites, as consumers might engage with brandrelated posts on social media via publishing their complaints as a result of product or service failure, so as to share this information with many others in order to be compensated.

\subsection{Brand-related Engagement Types: Consuming, Contributing, Creating}

In light of the previous discussion, it is proposed that consumers are either passive users, contributors, or active users when they engage with brand-related content (e.g., Muntinga et al., 2011; Shao, 2009). However, the existing literature lacks coverage around the reasons behind consumers' different types of brand-related engagement (Heinonen, 2011) on social media. Therefore, it appears timely and important to identify the motivations behind brandrelated engagement on social networking sites for greater theoretical understanding. While several studies show that McQuail's (1983) classification of motivations for using media can be applied to social media usage (e.g., Muntinga et al., 2011), self-determination theory is found to be a valuable framework with which to understand individuals' eWOM engagement behaviour (Wang et al., 2016). As a result, the conceptual framework (see Table II) used in this study is constructed through the inclusion of motives relating to enjoyment, communication (socialising), altruism (helping the company and helping others), positive empowerment, reward (remuneration) (Muntinga et al., 2011) and negative empowerment motives in order to define consumers' motives for engaging with brands and other people's brand-related posts. Furthermore, the seeking compensation motive from management 
literature, which has not been investigated previously in brand-engagement related literature, is added to the framework. 
Table II. Conceptual Framework and Justification for Motivations of Brand-related Engagement

\begin{tabular}{lll}
\hline Motivation & Key Characteristic(s) & Theoretical Underpinning \\
\hline $\begin{array}{l}\text { Enjoyment } \\
\text { Self-determination theory }\end{array}$ & $\begin{array}{l}\text { It refers to entertainment fun and amusement } \\
\text { (Yoo and Gretzel, 2008). }\end{array}$ & $\begin{array}{l}\text { It has an impact on consumers to engage with eWOM (Yoo } \\
\text { and Gretzel, 2008). }\end{array}$ \\
Information-seeking & It refers to seeking advice and risk reduction & It is established as a factor in eWOM studies (e.g., Hennig- \\
& (Muntinga et al., 2011). It also refers to a need for & Thurau et al., 2004) and a motive of consumers' brand-related \\
& receiving information (Blumler, 1979). & engagement on social media (Buzeta et al., 2020; Muntinga \\
& & et al., 2011).
\end{tabular}

\section{Helping Others}

(Positive Altruism)

Concern for others

(Negative Altruism)

Empowerment (positive

and negative)
The desire of helping others (Batson, 1991;

Sundaram et al., 1998).

Concern for others to protect them from making wrong decisions (Hennig-Thurau et al., 2004).

Social media gives empowerment to consumers to speak about brands and organisations (Bertot et al., 2010)
Established as a factor in WOM (e.g., Alexandrov et al., 2013) and eWOM studies (Hennig-Thurau et al., 2004).

Established as a factor in eWOM and has an impact on eWOM (Hennig-Thurau et al., 2004).

It has been employed as a motive to understand consumers' engagement with brand-related content on social media (Buzeta et al., 2020; Muntinga et al., 2011). 
External reward

(Remuneration)

(Self-determination

Theory)

Seeking compensation

from organisations

(Justice Theory)

Socialising

(communication)

(Uses and Gratifications

Theory

\& Self-determination

theory)

Expressing negative

feelings

Balance Theory
It refers to economic incentives (Buzeta et al., 2020; Wang and Fesenmaier, 2003), job-related benefits (Nov, 2007) and personal wants (Hars and $\mathrm{Ou}, 2001)$. It is associated with extrinsic motivation (Deci and Ryan, 2000)

Complaint for gathering tangible benefits from organisations (Davidow, 2003).

It refers to intrinsic motivation which is based on a need for enjoyment and being connected (Jeon et al., 2011).

It is associated with negative eWOM as a result of consumers' dissatisfying experiences (Hennig-

Thurau et al., 2004 ; Yoo and Gretzel, 2008).
Established as a motivation to understand consumers' brandrelated engagement on social media (Muntinga et al., 2011).

Not studied as a motivational factor of eWOM. People may provide feedback due to experiencing product failure (e.g., Davidow, 2003).

It has an impact on eWOM communication (Wojnicki and

Godes, 2011) and social media usage (Rathnayake and

Winter, 2018)

Established as a factor in eWOM literature (Hennig-Thurau et al., 2004 ; Yoo and Gretzel, 2008). 
As this review shows, each brand-related engagement type may be triggered by different motivations, but no study to date has identified which motivation(s) may influence each brand-related engagement type. To address this gap the current study conceptualises each brand-related engagement type (consuming, contributing, creating) through examining the motivations influencing consumers to engage with brand-related content on social media. Furthermore, this research separately investigates consumers' engagement based on their interaction (e.g., consuming and contributing) with brands and other people's brand-related posts, and creating will be looked at in relation to positive and negative motives.

\section{Methodology}

\subsection{Research Design}

A sequential mixed-method approach was implemented to establish a motivation framework of influences on consumers' engagement with different types of brand-related engagement behaviour. This two-stage research design proposes an appropriate method where the research tests the elements of an emergent theory resulting from the qualitative phase and employs this to generalise quantitative findings from different samples (Morgan, 1998). Initially qualitative semi-structured interviews explored the perceptions and opinions of participants to confirm existing motivations from existing literature as well as define any unknown motivations to provide a general understanding of whether they drive consumers to engage with different brand-related posts through consuming, contributing, and creating. These findings provided the measurement of motivations for each brand-engagement type in the qualitative method (online survey).

\subsection{Participant Recruitment}

A sample of active 'personal' Facebook and/or Twitter users (i.e., people not selling or marketing any organization's' products or services) over the age of 18 years were recruited. 
Participants were filtered to ensure they either consumed (i.e., people who only read brandrelated posts), contributed (to) (i.e., people who liked, commented, retweeted, or quoteretweeted brand-related posts), or created (i.e., people create and publish their brand-related content) brand-related posts on social networking sites for both the quantitative and qualitative data collection stages. To make the data set more manageable respondents were asked about their behaviour in relation to Facebook and Twitter. These were considered appropriate platforms to focus on as they were the two most popular social networking sites in the UK and have the greatest reach (OfCom 2020).

Interview respondents were recruited in the UK where users spend a quarter of their day on social media (Ofcom 2020). For the quantitative stage, a link to the survey was posted on Linkedln and under related pages on Instagram, Facebook, and Twitter. Participants were randomly rewarded with $£ 10$ Amazon vouchers to incentivise and to maximise completion for the quantitative stage.

\subsubsection{Stage 1: Semi-structured Interviews}

Exploratory research through twelve semi-structured interviews explored and identified the underlying motivations of brand-related engagement types in general. Respondents consisted of 5 males and 7 females aged between 18 and 55 years who all used social media, in particular Facebook and Twitter. Content analysis, following the processes defined by Kolbe and Burnett (1991), was utilised with one of the co-authors and an independent researcher reviewing the transcripts and agreeing on the themes within the data.

Initial analysis identified 15 different overall themes. The data showed that, while consuming brand-related posts was triggered by information seeking and enjoyment, consumers who contribute to brand-related posts on social networking sites were influenced by reward, enjoyment, helping the company, communication (socialising), and empowerment. The motives for creating brand-related posts are personal identity, enjoyment, 
helping others, warning others, reward, empowerment (positive and negative), communication (socialising), and seeking compensation. Whilst this stage confirmed motivations present in past literature, it also identified a new motive not previously realised seeking compensation. It was found as a negative motive that drives consumers to create brand-related eWOM posts as a result of a negative purchase and brand experience.

The qualitative content analysis of the interview material items as well as previous literature provided valuable insights into defining a list of motivations to take forward and utilise in constructing scale items for the subsequent quantitative approach. Previous literature items were modified to suit the context of the present study by using qualitative data findings.

\subsubsection{Stage 2: Online Survey}

To further substantiate these preliminary findings, this study used the items of brandrelated motives, generated from the semi-structured interviews and previous literature in the online survey as variables, to discover the main motivations of consuming, contributing, and creating brand-related posts on social media.

Each construct was measured on a 5-point Likert scale ( 5 = strongly agree to 1 strongly disagree). The questionnaire contained 65 different motivation items designed to identify motives for each engagement type (consuming, contributing, creating).

\section{Analysis}

\subsection{Exploratory Factor Analysis}

Factor analysis was employed to detect the broader fundamental evaluative dimensions (Hair et al., 2019) by summarising the scale items into a smaller set of new factors with minimum loss of information (Robinson et al., 1991). Principal Component Analysis (PCA) was utilised to maximise the variance explained for any number of factors, in order to assess 
the consistency and dimensionality of the motivation items' scales. Interpretation of the factors aimed to observe the underlying dimensions that combined the group of variables and significant factors loading on it through using Varimax rotation. Whilst Tabachnick and Fidell (2001) suggest that loadings of 0.32 and above should be interpreted, Hair et al. (2019) suggest factor loadings of 0.40 and above are considered significant. For this research, a factor loading of 0.40 and above was considered significant.

\subsection{Multiple Regression}

To define the different motivations that predict consuming, contributing, and creating brand-engagement behaviour multiple regression analysis was carried out. Motives of creating brand-related posts, consuming brand-related posts, and contributing to brand-related posts were used as the Independent Variables (IVs) and frequency of engaging with these types of brand-related posts were used as the dependent variables ( see Appendix 1). Frequency of creating, contributing to, and consuming brand-related posts was measured as ordinal variables, with categories; every day, once a week, 2-4 times a week, fortnightly, once a month, every 3-4 months, every 6 months, and every 12 months.

Correlation coefficients between the DVs and IVs were calculated to ensure the sample was suitable for multiple regression analysis using SPSS version 23. Correlation coefficients were carried out between all DVs and IVs for each brand-related engagement type. In order to define any issues with multicollinearity amongst the IVs, the correlation matrices were constructed for each engagement type model. A correlation of 0.9 or above was considered as substantial multicollinearity (Hair et al., 2019); however, this was not found in these engagement type models.

\section{Results}




\subsection{Respondent Characteristics}

The resulting sample (Table III) comprised $41.3 \%$ male and $58.7 \%$ female. The sample showed different levels of education, with most respondents having at least a bachelor's or Master's degree. The majority of the sample used social networking sites every day $(91.1 \%)$.

Table III: Sample Characteristics of Survey Respondents

\begin{tabular}{|c|c|c|}
\hline Variable & & Percentage \\
\hline \multirow[t]{2}{*}{ Gender } & Male & $41.3 \%$ \\
\hline & Female & $58.7 \%$ \\
\hline \multirow[t]{7}{*}{ Age } & $18-25$ & $8.4 \%$ \\
\hline & $26-30$ & $18.7 \%$ \\
\hline & $31-35$ & $14.2 \%$ \\
\hline & $36-45$ & $25.3 \%$ \\
\hline & $46-55$ & $13.3 \%$ \\
\hline & $56-65$ & $15.1 \%$ \\
\hline & $65+$ & $4.9 \%$ \\
\hline \multirow[t]{8}{*}{ Education } & Up to General Certificate of & $17.8 \%$ \\
\hline & Secondary School (GCSE) & \\
\hline & A level & $15.1 \%$ \\
\hline & Some college & $17.3 \%$ \\
\hline & Undergraduate degree & $28.4 \%$ \\
\hline & Postgraduate & $17.8 \%$ \\
\hline & Doctorate & $2.2 \%$ \\
\hline & Other & $1.3 \%$ \\
\hline \multirow[t]{7}{*}{ Employment } & Full-time & $54.7 \%$ \\
\hline & Part-time & $16.4 \%$ \\
\hline & Unemployed looking for work & $4.9 \%$ \\
\hline & Unemployed not looking for work & $8.9 \%$ \\
\hline & Retired & $7.6 \%$ \\
\hline & Student & $5.8 \%$ \\
\hline & Other & $1.7 \%$ \\
\hline \multirow[t]{3}{*}{ Frequency of social media usage } & Everyday & $91.1 \%$ \\
\hline & 2-4 times a week & $5.8 \%$ \\
\hline & Once a week & $2.7 \%$ \\
\hline
\end{tabular}




\begin{tabular}{|c|c|c|}
\hline & Once a fortnight & $0.4 \%$ \\
\hline \multirow[t]{6}{*}{ Frequency of consuming } & Everyday & $45.9 \%$ \\
\hline & 2-4 times a week & $25.4 \%$ \\
\hline & Once a week & $19.3 \%$ \\
\hline & Once a fortnight & $6.6 \%$ \\
\hline & Once a month & $2.2 \%$ \\
\hline & Every 3-4 months & $0.6 \%$ \\
\hline \multirow[t]{6}{*}{ Frequency of contributing } & Everyday & $45.9 \%$ \\
\hline & 2-4 times a week & $25.4 \%$ \\
\hline & Once a week & $19.3 \%$ \\
\hline & Once a fortnight & $6.6 \%$ \\
\hline & Once a month & $2.2 \%$ \\
\hline & Every 3-4 months & $0.6 \%$ \\
\hline \multirow[t]{8}{*}{ Frequency of creating } & Everyday & $9.2 \%$ \\
\hline & 2-4 times a week & $17.7 \%$ \\
\hline & Once a week & $8.5 \%$ \\
\hline & Once a fortnight & $12.3 \%$ \\
\hline & Once a month & $15.4 \%$ \\
\hline & Every 3-4 months & $9.2 \%$ \\
\hline & Every 6 months & $15.4 \%$ \\
\hline & Every 12 months & $12.3 \%$ \\
\hline
\end{tabular}

Three different sets of questions were constructed in order to measure consumers' different types of brand-related engagement. This resulted in responses from 170 people who consumed brand-related posts from brands and other people, 146 responses from those who contributed to brand-related posts from brands and other people, and 130 responses from people who created brand-related posts. Overall, this study contained 225 responses, which was considered a sufficient sample size for the proposed analysis (Hair et al., 2019). 


\subsection{Motivations for Brand-related Engagement Types}

\subsubsection{Consuming Brand Related Posts from Brands and Other People}

The factors significantly influencing the frequency of consuming brand-related posts from brands are enjoyment and information-seeking motives (Table IV). However, whilst enjoyment is also significant for consuming brand-related posts from other people, information-seeking is not. Whilst Flynn et al. (1996) found that consumers tend to seek information from other people when they make a purchase decision, the current study shows that consumers tend to seek information more frequently from brands than other people.

Table IV. Consuming Brand-related Posts on Social Networking Sites

\begin{tabular}{lll}
\hline Engagement type & Motive & $\begin{array}{l}\text { Frequency of } \\
\text { consuming brand- } \\
\text { related posts }\end{array}$ \\
& & $\mathbf{. 0 0 2}^{* *}$ \\
\hline Consuming brand-related & Enjoyment & $\mathbf{. 0 4 2}^{*}$ \\
posts from brands & Information seeking & $\mathbf{. 0 0 0 ^ { * * }}$ \\
Consuming brand-related & Enjoyment & .435 \\
posts from other people & Information seeking & \\
\hline
\end{tabular}

** Significant at $\mathrm{p}<0.01 ; *$ Significant at $\mathrm{p}<0.05 ; \mathrm{N}=170$

\subsubsection{Contributing to Brand Related Posts from Brands and Other People}

The motives influencing the frequency of contributing to brand-related posts on social networking sites are shown in Table V. It can be seen that enjoyment and communication are the only motives found to be significant, and this is both in relation to contributing to brandrelated posts from brands as well as other people on social networking sites.

In contrast to past research, the motives of helping the company, empowerment, and reward are not found significant. Hanna et al. (2011) stated consumers enjoy being part of 
brand-consumer conversations that are powered by social media. However, this study finds the empowerment motive to have no impact on contributing to brand-related posts from brands on social networking sites. Although reward has been found as a motivational strategy for repeating positive behaviour (e.g., Deci, 1971) and Hennig-Thurau et al. (2004) found consumers online brand-related activities may be motivated by expecting a reward from an organisation, the current study shows the reward motive to not influence consumers when they contribute to brand-related posts from both brands and other people.

Table V. Contributing to Brand-related Posts on Social Networking Sites

\begin{tabular}{lll}
\hline Engagement Type & Motive & $\begin{array}{l}\text { Frequency of contributing } \\
\text { to brand-related posts }\end{array}$ \\
\hline Contributing to brands' & Enjoyment & $\mathbf{. 0 0 1}$ \\
brand-related posts & Communication & $\mathbf{. 0 0 0}$ \\
& Helping the company & .119 \\
& Empowerment & .910 \\
& Reward & .565 \\
Contributing other people's & Enjoyment & $\mathbf{. 0 0 0}$ \\
brand-related posts & Communication & $\mathbf{. 0 4 6 *}$ \\
& Helping the company & .166 \\
& Empowerment & .459 \\
& Reward & .126 \\
\hline
\end{tabular}

** Significant at $\mathrm{p}<0.01 ; *$ Significant at $\mathrm{p}<0.05 ; \mathrm{N}=146$

\subsubsection{Creating Brand Related Posts}

The motives for creating brand related posts were split into positive and negative motives as outlined in Table VI. The motives of reward and enjoyment were found to positively influence the frequency of creating brand-related posts. 
The seeking compensation motive has a significant impact on the frequency of creating negative brand-related posts on social networking sites (Table VI). This can be explained by referring back to the semi-structured interview findings, which showed the majority of interviewees mentioning they mainly engage with negative brand-related posts on social media as a result of a negative purchase experience. Hence, they seek compensation by creating a negative brand-related post.

Table VI. Creating Brand-related posts on Social Networking Sites

\begin{tabular}{lll}
\hline Engagement type & Motive & $\begin{array}{l}\text { Frequency of creating } \\
\text { brand-related posts }\end{array}$ \\
\hline Creating positive brand- & Reward & $\mathbf{. 0 0 0}$ \\
related posts & Enjoyment & $\mathbf{. 0 0 2}$ \\
& Helping the company & .148 \\
& Helping others & .374 \\
& Communication & .296 \\
& Empowerment & .835 \\
& Self-identity & .148 \\
Creating negative brand- & Warn others & .213 \\
related posts & Empowerment & .320 \\
& Seeking compensation & $\mathbf{. 0 0 0}$
\end{tabular}

** Significant at $\mathrm{p}<0.01 ; \mathrm{N}=124$

\section{Discussion}

\subsection{Theoretical Implications}

This research contributes significantly to understanding consumer brand-related engagement behaviour on social media as it investigates motivations behind consumer engagement with brand-related posts created by both brands and other people. Whilst past literature suggests several motivations may influence consumers to engage with brand-related 
posts on digital platforms, including consumer online review sites, social media sites, and discussion forums (e.g., Heinonen, 2011; Hennig-Thurau et al., 2004, Muntinga et al., 2011), previous consumer brand-related engagement studies (e.g., Alexandrov et al., 2013; HennigThurau et al., 2004; Sundaram et al., 1998) only focus on consumer-to-consumer interaction. The interactive nature of social media has shifted the conversation from 'organisation-toconsumer' to 'consumer-to-consumer', however, it does not remove organisations from this consumer-to-consumer communication on social media (Sweeney et al., 2014). Therefore, it is important to understand the communication between consumers- consumers as well as consumers-brands.

Whilst Muntinga et al. (2011) investigated consumer motivations for consuming brandrelated posts created by both brands and other consumers, their research did not explore levels of engagement. Bridging this gap, the current study focused on consuming and contributing to brand-related posts on social networking sites through investigating consumers' brand-related engagement with brands and other people's posts separately. Results reveal that consumers who are driven by the enjoyment motive for contributing to brand-related posts from brands and other people, tend to contribute to brand-related posts more frequently. This supports previous studies that found contributing to mobile apps (e.g., Chua et al., 2012) and open-source software projects (Lakhani and Wolf, 2005; Nov, 2007) provided a good source of entertainment. Further motives found support through this study: the entertainment motive triggers the contribution behaviour of brand-related posts on social networking sites, and the communication motive has a significant influence upon the frequency of contributing to both brand and other people's brand-related posts on social media. This supports the work of Shao (2009), who noted the activity of contributing to content on user-generated content sites is often driven by the desire for social connections. 
Social interaction was also found by McKenna and Bargh (1999), and Popp et al. (2016), in the context of virtual brand community motivations.

Findings identify the information-seeking motive for consuming brand-related posts from other people has no impact on the frequency of consuming brand-related posts on social networking sites, despite Mangold and Faulds (2009) finding consumers use social media as a more reliable information source than firm-generated sources. Scholars and practitioners have suggested that within social media, consumers tend to trust their peers' reviews more than what advertisers say (Brightlocal, 2017; Coulter and Roggeveen, 2012). However, the results of the current study suggest consumers tend to seek brand-related information from brands more often than other people who share their brand-related information and experiences. This could be due in part to social media gradually becoming a source for consumers to interact directly with brands in real-time. Hence, it appears consumers seek brand-related information created by brands increasingly often.

According to this research, consumers who are driven by the enjoyment motive tend to create brand-related posts more frequently. Hence, consumers produce brand-related posts as they enjoy creating these posts. While enjoyment is covered as motivation in most social media motivation studies (e.g., Stoeckl et al., 2007), Muntinga et al. (2011) cover it as an entertainment motive through identifying sub-motivations. Whilst creating general social media content can be related to a wide range of entertainment-related motivations (Courtois et al., 2009), enjoyment is found to drive the creation of brand-related content (Berthon et al., 2008).

Drawing from self-determination theory, this study examined external reward as the remuneration motive which has been investigated in previous social media and motivation literature (e.g., Bhattacharya, 2016; Muntinga et al., 2011; Nov 2007; Wang and Fesenmaier, 2003). The external reward has been recognised as a powerful force to control human 
behaviour (Deci and Ryan, 2000). In previous studies, the reward has been found to have a strong impact on moving consumers' engagement from consuming to contributing and creating (Buzeta et al., 2020; Vale and Fernandes, 2017). Buzeta et al. (2020) also investigated external reward as 'remuneration' which was found to be a strong influence on brand-related post creation on social media. Rewards in a format of promotion, sales, and discount also have been found to have a positive impact on consumers' brand-related engagement on social media (Liu et al., 2017). As the reward can be in different forms (Deci and Ryan, 2000), the current research investigated external rewards as tangible or intangible rewards that consumers expect as a result of their positive brand-related engagement posts on social media. Hence, external motivation is found to be a key driver that increases the frequency of creating brand-related posts on social networking sites. Although empowerment motive has been identified as a key motive for content creation in previous literature (e.g., Saridakis et al., 2016), this study shows empowerment has no impact on creating brandrelated posts on social media.

Exploring the creation of negative brand-related posts on social networking sites led to four motivations being identified through the qualitative findings. However, only the seeking compensation motive was found as a key driver that increases the frequency of creating brand-related posts on social networking sites in the quantitative phase. While seeking compensation is investigated in the management literature (Estelami, 2000; Hocutt et al., 2006; Mount and Mattila, 2000), it has not been specified in the brand-related literature. Gelbrich and Roschk (2011) found that consumers who complained about a product or service desired to be compensated. According to the current study seeking compensation is a key driver that increases the frequency of creating a brand-related post on social networking sites. Hence, consumers driven by the seeking compensation motive tend to create brandrelated posts more frequently. The results support the view of justice theory - that consumers 
driven by the seeking compensation motive tend to create brand-related posts as they seek an organisational response to a complaint (Smith et al., 1999).

\subsection{Managerial implications}

An understanding of the process of engaging with brand-related posts is vital for brands to recognise how they can create brand-related posts that appeal to consumers and encourage engagement through consuming, contributing (to), and creating any brand-related content on social networking sites. Before companies start creating an online presence on social media, they need to understand not only these different brand-related engagement types but also the motivations behind them. Hence, this paper provides valuable insights for social media marketers regarding online consumer behaviour.

Companies should use social media sites to increase awareness of their brand's services or products in general. According to Sprout Social Index (2019) 66\% of consumers follow retailers on social networking sites to learn about sales and keep up with new products. Findings from this study show evidence that consumers who read brand-related posts from brands are driven by the information-seeking motive. Hence, social media should provide the information consumers need. Furthermore, this study finds that consumers driven by the enjoyment motive consume brand-related posts from brands and other consumers. Advertisers on social media have an opportunity to create a personalised environment (Hausman et al., 2014), where brands can create enjoyable advertising campaigns to stimulate engagement with content through consuming (e.g., reading).

In studying consumer motivations for contributing to brand-related posts on social media it was found that consumers who are driven by enjoyment and communication motives contribute to brand-related posts on social media. Therefore, companies should create social media campaigns that lead to communication between brands and consumers by considering 
which motives impact their brand-related engagement. Companies can create social media campaigns that encourage consumers to tag or share brand-related posts with their friends, families, and e-friends. Furthermore, consumers also contribute to brand-related posts more frequently if driven by the enjoyment motive, and companies should therefore focus on making brand pages an enjoyable space for consumers.

To understand the most active brand-related engagement type - creating - brands need to know the motivations that influence consumers to articulate brand-related posts on social media sites. This will help drive engagement, awareness and consumer services. This study found consumers tend to be driven by enjoyment and external reward when they create brand-related posts on social media. Hence, brands should create campaigns in which consumers can receive external rewards (e.g., intangible and/or tangible) from brands and spread brand-related posts on social media.

This research has examined a key driver that motivates consumers to produce negative brand-related posts: seeking compensation. Complaints about compensation claims are becoming increasingly commonplace on social media (Causon, 2015). Hence, brands need to have a proactive strategy to manage these negative brand-related posts, driven by seeking the compensation motive, in order to prevent damage to their brand reputation.

\section{Conclusions}

It has been seen that brand-related engagement has a tremendous impact on consumer behaviour. The discussion of previous brand-related engagement studies illustrates that there is a lack of understanding of consumer brand-related engagement types. Additionally, there is clear evidence that consumer brand-related engagement can vary depending on motivations. Hence knowing the motivations behind each type of brand-related engagement behaviour can 
provide valuable insight for brands and organisations in terms of consumer brand-related behaviour on social media.

Understanding motivations is crucial for brands and organisations in order to evaluate consumers' brand-related engagement behaviour on social networking sites. This study provides a tested conceptual framework for each brand-related engagement type on social networking sites and outlines clear evidence that there is a relationship between social networking site usage and brand-related post engagement on social media.

\subsection{Limitations and Future Research}

This paper focuses on the motivations behind consumers' brand-related engagement. Although motivation is one of the major factors that can influence individuals to perform a particular behaviour, there can be other factors that need further exploration such as technological, social/demographic factors, and personality factors such as opinion leadership, perceived ease of use, and perceived entertainment. Further exploration of these areas is desirable (Tang et al., 2016).

Although, this study has attempted to present a general understanding of consumers' brand-related engagement types, it cannot be considered representative of the phenomenon. For example, this study investigated several motives to define what motivates consumers to engage with different brand-related engagement types. However, there may be other factors (e.g., situational factors, characteristic factors, etc.) that influence consumers to engage with brand-related posts on social networking sites.

Moreover, this study has provided important insights into the nature of brand-related engagement behaviour, and as such, has major implications for the development of advanced communications for both consumer-to-consumer and consumer-to-brand on social networking sites, and brands' social media marketing strategies. Although this motivation 
framework has clear insights regarding consumer behaviour, future research should be employed to update these motives. The scale developed to measure brand-related engagement behaviour could be applied across different industries. Further research is therefore required to implement this model for consumers' brand-related engagement by looking at different sectors such as food, fashion, and tourism.

\section{References}

Alexandrov, A., Lilly, B. and Babakus, E. (2013), "The effects of social- and self-motives on the intentions to share positive and negative word of mouth." Journal of the Academy of Marketing Science, Vol. 41 No 5, pp.531-546.

Algesheimer, R., Dholakia, U.M. and Herrmann, A. (2005), "The social influence of brand community: Evidence from European car clubs", Journal of Marketing, Vol. 69 No. 3, pp.19-34.

Baldus, B. J., Voorhees, C. and Calantone, R. (2015), "Online brand community engagement: Scale development and validation", Journal of Business Research, Vol. 68 No. 5, pp.978-985.

Batson, C. D. (1991), The altruism question: Toward a social-psychological answer, Hillsdale, NJ: Erlbaum.

Berthon, P., Pitt, L. and Campbell, C. (2008), "Ad Lib: When Customers Create the Ad." California Management Review, Vol. 50 No. 4, pp.6-30.

Bertot, J. C., Jaeger, P. T. and. Grimes, J. M. (2010), "Using ICTs to create a culture of transparency: E-government and social media as openness and anti-corruption tools for societies", Government Information Quarterly, Vol. 27 No. 3, pp.264-271.

Bhattacharya, M. (2016), "The Curse of Competitive Crowd Intelligence", AAAI Spring Symposium Series, available at: https://www.aaai.org/ocs/index.php/SSS/SSS16/paper/view/12716/11962 (accessed 30 January 2019). 
Blumler, J. G. 1979. "The role of theory in uses and gratifications studies" , Communication Research, Vol. 6 No. 1, pp.9-36.

Bock, G.W., Zmud, R.W., Kim, Y.G. and Lee, J.N. (2005), "Behavioural intention formation in knowledge sharing: Examining the roles of extrinsic motivators, social-psychological forces, and organizational climate", MIS Quarterly, Vol.29 No. 1, pp.87-111.

Bolton, R., and Saxena-Iyer, S. (2009), "Interactive Services: A Framework, Synthesis and Research Directions", Journal of Interactive Marketing, Vol. 23 No.1, pp.91-104.

Brightlocal, (2017), “Local Consumer Review Survey 2020”, available at: https://www.brightlocal.com/research/local-consumer-review-survey/ (accessed 10 April 2020).

Brodie, R. J., Ilic, A., Juric, B., and Hollebeek, L. (2013), "Consumer engagement in a virtual brand community: An exploratory analysis", Journal of business research, Vol. 66 No.1, pp.105-114.

Bumgarner, B.A. (2007), "You have been poked: exploring the uses and gratifications of Facebook among emerging adults", available at: https://journals.uic.edu/ojs/index.php/fm/article/view/2026/1897 (accessed 20 December 2019).

Buzeta, C., De Pelsmacker, P. and Dens, N. (2020), "Motivations to Use Different Social Media Types and Their Impact on Consumers' Online Brand-Related Activities (COBRAs)", Journal of Interactive Marketing, Vol. No. 52, pp.79-98.

Causon, J. (2015), "Customer complaints made via social media on the rise", available at: https://www.theguardian.com/media-network/2015/may/21/customer-complaints-socialmedia-rise (accessed 30 January 2019).

Calder, B.J., Malthouse, E.C. and Schaedel, U. (2009), "An experimental study of the relationship between online engagement and advertising effectiveness", Journal of Interactive Marketing, Vol. 23 No. 4, pp.321-331.

Chan, K. W. and Li, S. Y. (2010), "Understanding consumer-to-consumer interactions in virtual communities: The salience of reciprocity" Journal of Business Research, Vol.63 No, 9-10, pp.1033-1040.

Chatzisarantis, N. L. and Biddle, S. J. (1998), "Functional significance of psychological variables that are included in the Theory of Planned Behaviour: a Self-Determination Theory approach to the study of attitudes, subjective norms, perceptions of control and intentions", European Journal of Social Psychology, Vol. 28 No. 3, pp.303-322.

Cheung, C. M. K. and Lee, M. K. O. (2012), "What drives consumers to spread electronic word of 
mouth in online consumer-opinion platforms", Decision Support Systems, Vol. 53, No. 1, pp.218-225.

Chu, S-C. and Kim. Y. (2011), "Determinants of consumer engagement in electronic wordof-mouth (eWOM) in social networking sites", International Journal of Advertising, Vol. 30 No. 1 , pp.47-75.

Chua, A.Y., Goh, D. H. L. and Lee, C. S. (2012), "Mobile content contribution and retrieval: An exploratory study using the uses and gratifications paradigm", Information Processing \& Management, Vol. 48 No. 1, pp.13-22.

Conger, J.A. and Kanungo, R. N. (1988), "The empowerment process: Integrating theory and practice", Academy of Management Review, Vol. 13 No. 3, pp. 471-482.

Coulter, K. S. and Roggeveen, A. (2012), "Like it or not", Consumer responses to word-ofmouth communication in on-line social networks, Management Research Review, Vol. 35 No.9, pp.878-899.

Courtois, C., Mechant, P., De Marez, L. and Verleye, G. (2009), "Gratifications and seeding behaviour of online adolescents", Journal of Computer-Mediated Communication, Vol. 15 No. 1, pp. 109-137.

Cruz, R. E., Leonhardt, J. M. and Pezzuti, T. (2017), "Second Person Pronouns Enhance Consumer Involvement and Brand Attitude", Journal of Interactive Marketing, Vol. 39, pp. 104-116.

Cvijikj, I.P. and Michahelles, F. (2013), “Online engagement factors on Facebook brand pages", Social network analysis and mining, Vol. 3 No. 4, pp.843-861.

Davidow, M. (2003), "Organizational Responses to Customer Complaints: What Works and What Doesn't", Journal of Service Research, Vol. 5 No. 3, pp. 225-250.

De Angelis, M., Bonezzi, A., Peluso, A. M., Rucker, D. D. and Costabile, M. (2012), "On Braggarts and Gossips: A Self-Enhancement Account of Word-of-Mouth Generation and Transmission", Journal of Marketing Research, Vol. 49 No. 4, pp.551-563.

Deci, E. L., and Ryan, R. M. (2000), "The "What" and "Why" of Goal Pursuits: Human Needs and the Self-Determination of Behaviour", Psychological Inquiry, Vol. 11 No.4, pp.227-268.

Deci, E.L. and Ryan, R.M. (2012), "Self-determination theory”, In Handbook of Theories of Social Psychology, Vol. 1, ed. PAM Van Lange, AW Kruglanski, ET Higgins, Thousand Oaks, CA: Sage, pp. 416-37.

Dellarocas, C. (2003), "The Digitization of Word of Mouth: Promise and Challenges of Online Feedback Mechanisms", Management Science, Vol. 49 No.10, pp.1407-1424. 
Denegri-Knott, J., Zwick, D. and Schroeder, J. E. (2006), "Mapping consumer power: an integrative framework for marketing and consumer research", European Journal of Marketing, Vol.40 No. 9/10, pp. 950-971.

De Vries, L., Gensler, S. and Leeflang, P.S. (2012), "Popularity of brand posts on brand fan pages: An investigation of the effects of social media marketing", Journal of Interactive Marketing, Vol. 26 No. 2, pp.83-91.

De Vries, L., Peluso, A.M., Romani, S., Leeflang, P.S.H. and Marcati, A. (2017), "Explaining consumer brand-related activities on social media: an investigation of the different roles of selfexpression and socializing motivations", Computers in Human Behaviour, Vol. 75, pp.272-282.

Dichter, E. (1996), "How Word-of-Mouth Advertising Works", Harvard Business Review, Vol. 44 No.147.

Dholakia, U.M., Bagozzi, R.P. and Pearo, L.K. (2004), "A social influence model of consumer participation in network-and small-group-based virtual communities", International journal of research in marketing, Vol. 21 No. 3, pp.241-263.

Dolan, R. Conduit, J. Fahy, J. and Goodman, S. (2016), "Social media engagement behaviour: A uses and gratifications perspective", Journal of Strategic Marketing, Vol. 24 No. 3-4, pp.261277.

Dolan, R., Conduit, J., Fahy, J. and Goodman, S. (2017), "Social media: communication strategies, engagement and future research directions", International Journal of Wine Business Research, Vol. 29 No. 1, pp. 2-19.

Dolan, R., Conduit, J., Frethey-Bentham, C., Fahy, J., and Goodman, S. (2019), "Social media engagement behaviour: A framework for engaging customers through social media content", European Journal of Marketing, Vol 53 No. 10, pp.2213-2243.

Estelami, H. (2000), "Competitive and procedural determinants of delight and disappointment in consumer complaint outcomes", Journal of Service Research, Vol. 2 No. 3, pp.285-300.

Feick, L. F. and Price, L. L. (1987), "The Market Maven: A Diffuser of Marketplace Information", Journal of Marketing, Vol.51 No.1, pp.83-97.

Flynn, L.R., Goldsmith, R. E. and Eastman, J. K. (1996), "Opinion leaders and opinion seekers: two new measurement scales", Journal of the Academy of Marketing Science, Vol. 24 No. 2, pp.137147.

Gelbrich, K. and Roschk, H. (2011), "A Meta-Analysis of Organizational Complaint Handling and Customer Responses", Journal of Service Research, Vol. 14, No. 10, pp.24-43. 
Hair, J., Black W. C., Babin B. and Anderson R. (2019), Multivariate Data Analysis - 8th Edition. London, UK: Cengage.

Hanna, R., Rohm, A. and Crittenden, V.L. (2011), "We're all connected: The power of the social media ecosystem", Business horizons, Vol. 54 No. 3, pp.265-273.

Hars, A., and Ou, S. (2001), "Working for free? Motivations of participating in open source projects", International Journal of Electronic Commerce, Vol. 6 No. 2, pp. 25-39.

Hausman, A., Soares, A.M. and Pinho, J.C. (2014), "Advertising in online social networks: the role of perceived enjoyment and social influence", Journal of Research in Interactive Marketing, Vol. 8, No. 3, pp. 245-263.

Heinonen, K. (2011), "Consumer activity in social media: Managerial approaches to consumers' social media behaviour", Journal of Consumer Behaviour, Vol. 10, No. 6. pp.356-364.

Hennig-Thurau, T., Gwinner, K. P, Walsh, G. and Gremler, D. D (2004), "Electronic wordof-mouth via consumer-opinion platforms: What motivates consumers to articulate themselves on the Internet?", Journal of Interactive Marketing, Vol. 18 No. 1, pp.38-52.

Hocutt, M. A., Bowers M. R. and Donavan D. T. (2006), "The art of service recovery: fact or fiction?", Journal of Services Marketing, Vol. 20 No. 3, pp. 199-207.

Hollebeek, L.D., Glynn, M.S. and Brodie, R.J. (2014), "Consumer brand engagement in social media: Conceptualization, scale development and validation", Journal of interactive marketing, Vol. 28 No. 2, pp.149-165.

Hollebeek, L.D. and Macky, K. (2019), "Digital content marketing's role in fostering consumer engagement, trust, and value: framework, fundamental propositions, and implications", Journal of Interactive Marketing, Vol. 45, pp. 27-41.

Hung, K. H., and Li, S. Y. (2007), "The Influence of eWOM on Virtual Consumer Communities: Social Capital, Consumer Learning, and Behavioural Outcomes", Journal of Advertising Research, Vol. 47 No. 4, pp. 485-495.

Jeon, S.H., Kim, Y.G. and Koh, J. (2011), "Individual, social, and organizational contexts for active knowledge sharing in communities of practice", Expert Systems with applications, Vol. 38 No. 10, pp.12423-12431.

Kabadayi, S. and Price, K. (2014), "Consumer - brand engagement on Facebook: liking and commenting behaviours", Journal of Research in Interactive Marketing, Vol.8 No. 3, pp.203-223. 
Kaye, B. K. (2007), "Blog Use Motivations: An Exploratory Study", In Blogging,

Citizenship, and the Future of Media, edited by M. Tremayne, pp.127-148. New York, NY: Routledge.

Katz, E. and Foulkes, D. (1962), "On the use of the mass media as "escape": Clarification of a concept", Public opinion quarterly, Vol. 26 No. 3, pp.377-388.

Kolbe, R. H. and Burnett, M. S. (1991), "Content-Analysis Research: An Examination of Applications with Directives for Improving Research Reliability and Objectivity", Journal of Consumer Research, Vol. 18 No. 2, pp.243-250.

Kotler, P., Keller, K. L., Manceau, D. and Hemonnet-Goujot, A. (2019), Marketing Management $-16^{\text {th }}$ Edition. New York, NY: Pearson.

Kowal, J. and Fortier, M. S. (1999), "Motivational determinants of flow: Contributions from self-determination theory", The Journal of Social Psychology, Vol.139 No.3, pp.355368.

Kumar, N., Lang, K. R., and Peng, Q. (2005), “Consumer search behaviour in online shopping environments", In Proceedings of the 38th Annual Hawaii International Conference on System Sciences, pp. 175b-175b.

Lakhani, K. R., and Wolf, R. (2005), "Why Hackers Do What They Do: Understanding Motivation and Effort in Free/Open Source Software Projects", In Perspectives on Free and Open Source Software edited by J. Feller, B. Fitzgerald, S. Hissam, and K. Lakhani, Cambridge, MA: MIT Press, pp.3-23..

Lee, J-S., Tsang, N. and Pan, S. (2015), "Examining the differential effects of social and economic rewards in a hotel loyalty program", International Journal of Hospitality Management, Vol. 49, pp.17-27.

Li, C. and Bernoff, J. (2008), Groundswell: Winning in a world transformed by social technologies, Boston, MA: Harvard Business School Press.

Lin, F. and Huang, H. (2013), "Why people share knowledge in virtual communities? The use of Yahoo! Kimo Knowledge+ as an example", Internet Research, Vol. 23 No. 2, pp.133-159.

Liu, X., Burns, A.C. and Hou, Y. (2017), "An investigation of brand-related user-generated content on Twitter", Journal of Advertising, Vol. 46 No. 2, pp.236-247.

Ma, M. and Agarwal, R. (2007), "Through a glass darkly: Information technology design, identity verification, and knowledge contribution in online communities", Information Systems Research, Vol. 18 No. 1, pp. 42-67. 
Malthouse, E.C. and Calder, B.J. (2011), "Comment: engagement and experiences: comment on Brodie, Hollenbeek, Juric, and Ilic (2011)”. Journal of Service Research, Vol. 14 No. 3, pp.277-279.

Malthouse, E. and Hofacker, C. (2010), "Looking Back and Looking Forward with Interactive Marketing", Journal of Interactive Marketing, Vol. 24 No. 3, pp.181-184.

Mangold, W.G. and Faulds, D. J. (2009), "Social media: The new hybrid element of the promotion mix", Business Horizons, Vol. 52 No. 4, pp. 357-365.

Mattila, A. S. and Patterson, P. (2004), "Service recovery and fairness perceptions in collectivist and individualist contexts". Journal of Service Research, Vol. 6 No. 4, pp.336-346.

McKenna, K. Y. and Bargh, J. A. (1999), "Causes and consequences of social interaction on the Internet: A conceptual framework", Media Psychology, Vol. 1 No. 3. pp. 249-269.

McQuail, D. (1983), Mass Communication Theory. London, UK: Sage Publications.

Menon, S. (2001), "Employee Empowerment: An Integrative Psychological Approach", Applied Psychology, Vol.50 No. 1, pp.153-180.

Mishra, A.S. (2019), “Antecedents of consumers' engagement with brand-related content on social media", Marketing Intelligence \& Planning, Vol 37 No. 4, pp. 386-400.

Moldovan, S., Goldenberg, J. and Chattopadhyay, A. (2011), "The different roles of product originality and usefulness in generating word-of-mouth", International Journal of Research in Marketing, Vol. 28 No. 2, pp. 109-119.

Mount, D. J. and Mattila, A. (2000), "The Final Opportunity: The Effectiveness Of A Customer Relations Call Center In Recovering Hotel Guests", Journal of Hospitality \& Tourism Research, Vol. 24 No. 4, pp.514-525.

Morgan, D.L. (1998), "Practical strategies for combining qualitative and quantitative methods: Applications to health research", Qualitative health research, Vol. 8 No. 3, pp.362-376.

Muntinga, D. G., Moorman, M. and Smit, E. G. (2011), "Introducing COBRAs: Exploring motivations for brand-related social media use", International Journal of Advertising, Vol. 30 No. 1, pp. 13-46.

Norman, A.T. and Russell, C. A. (2006), "The Pass-Along Effect: Investigating Word-ofMouth Effects on Online Survey Procedures", Journal of Computer-Mediated Communication, Vol.11 No.4, pp.1085-1103. 
Nov, O. (2007), "What motivates Wikipedians?", Communications of the ACM, Vol. 50 No. 7, pp. 60-64.

OfCom (2020), "UK's internet use surges to record levels", available at: https://www.ofcom.org.uk/about-ofcom/latest/media/media-releases/2020/uk-internetuse-surges (accessed 27 July 2020).

Omnicore (2019), "Facebook by the Numbers: Stats, Demographics \& Fun Facts", available at: https://www.omnicoreagency.com/facebook-statistics/ (accessed 20 October 2019).

Park, N., Kee, K. F. and Valenzuela, S. (2009), "Being Immersed in Social Networking Environment: Facebook Groups, Uses and Gratifications, and Social Outcomes", CyberPsychology \& Behaviour, Vol. 12 No. 6, pp.729-733.

Piehler, R., Schade, M., Kleine-Kalmer, B. and Burmann, C. (2019), “Consumers' online brand-related activities (COBRAs) on SNS brand pages: An investigation of consuming, contributing and creating behaviours of SNS brand page followers" European Journal of Marketing Vol. 53 No. 9, pp. 1833-1853.

Pitta, D. A. and Fowler, D. (2005), "Online Consumer Communities and Their Value to New Product Developers", Journal of Product \& Brand Management, Vol. 14 No. 5, pp.283291.

Popp, B., Wilson, B. Horbel C. and Woratschek, H. (2016), "Relationship building through Facebook brand pages: the multifaceted roles of identification, satisfaction, and perceived relationship investment", Journal of Strategic Marketing, Vol. 24 No. 3-4, pp.278-294.

Rathnayake, C. and Winter, J.S. (2018), "Carrying forward the uses and grats 2.0 agenda: An affordance-driven measure of social media uses and gratifications", Journal of Broadcasting \& Electronic Media, Vol. 62 No.3, pp.371-389.

Ridings, C. M. and Gefen, D. (2004), "Virtual community attraction: Why people hang out online", Journal of Computer-Mediated Communication, Vol. 10 No. 1, pp.JCMC10110.

Robinson, J.P., Shaver, P.R. and Wrightsman, L.S. (1991), "Criteria for scale selection and evaluation", Measures of personality and social psychological attitudes, Vol. 1 No. 3, pp.1-16.

Rodgers, S., Wang, Y., Rettie ,R. and Alpert, F. (2007), "The Web Motivation Inventory: replication, extension and application to internet advertising", International Journal of Advertising, Vol. 26 Vol. 4, pp.447-476. 
Ryan, R. M. and Deci, E. L. (2000), "Intrinsic and extrinsic motivations: Classic definitions and new directions", Contemporary Educational Psychology, Vol. 25 No. 1, pp.54-67.

Sashi, C.M. (2012), “Customer engagement, buyer-seller relationships, and social media”. Management decision, Vol. 50 No. 2, pp. 253-272.

Saridakis, C., Baltas, G., Oghazi, P., and Hultman, M. (2016), "Motivation recipes for brandrelated social media use: A Boolean-FSQCA approach", Psychology \& Marketing, Vol. 33, No.12, pp. 1062-1070.

Schindler, R. M. and Bickart, B. (2005), "Published word of mouth: Referable, consumer generated information on the Internet", Online Consumer Psychology: Understanding and Influencing Consumer Behaviour in the Virtual World, edited by C. P. Haugtvedt, K. A. Machleit, and R. F. Yalch, pp. 32-58. Lawrence Erlbaum Associates Inc. Publishers: Mahwah, NJ.

Schivinski, B., Christodoulides, G. and Dabrowski, D. (2016), "Measuring Consumers' Engagement With Brand-Related Social-Media Content - Development and Validation of a Scale That Identifies Levels of Social-Media Engagement With Brands", Journal of Advertising Research, Vol. 56, No. 1, pp. 1-18.

Segev, S., Villar, M. E. and Fiske, R. M. (2012), "Understanding Opinion Leadership and Motivations to Blog: Implications for Public Relations Practice", Public Relations Journal, Vol. 6 No. 5.

Shao, G. (2009), "Understanding the appeal of user-generated media: a uses and gratifications perspective", Internet Research, Vol. 19 No. 1, pp. 7-25.

Smith, A. K., Bolton, R. N. and Wagner, J. (1999), "A Model of Customer Satisfaction with Service Encounters Involving Failure and Recovery", Journal of Marketing Research, Vol. 36 No. 3, pp. 356-372.

Sprout Social Index (2019), Edition XV: Empower and Elevate, available at: https://media.sproutsocial.com/uploads/Sprout-Social-Index-2019.pdf (accessed 14 August 2020).

Statista, (2019a), Daily time spent on social networking by internet users worldwide from 2012 to 2018 (in minutes), available at: https://www.statista.com/statistics/433871/dailysocial-media-usage-worldwide/ (accessed 13 October 2019).

Statista, (2020a), "Number of social network users worldwide from 2017 to 2025", available at: https://www.statista.com/statistics/278414/number-of-worldwide-social-networkusers/ (accessed 20 July 2020). 
Statista, (2020b), "Social media - Statistics \& Facts", available at:

https://www.statista.com/topics/1164/social-networks/ (accessed 20 August 2020).

Stoeckl, R., Rohrmeier, P. and Hess, T. (2007), "Motivations To Produce User Generated Content: Differences Between Webloggers And Videobloggers”, BLED 2007 Proceedings. 30, available at: https://aisel.aisnet.org/cgi/viewcontent.cgi?article=1029\&context=bled2007 $($ accessed 20 December 2018).

Sundaram, D. S., Mitra, K. and Webster, C. (1998), "Word-of-Mouth Communications: A Motivational Analysis", Advances in Consumer Research, Vol. 25, pp. 527-531.

Sweeney, J., Soutar, G. and Mazzarol, T. (2014), "Factors enhancing word-of-mouth influence: positive and negative service-related messages", European Journal of Marketing, Vol. 48 No.1/2, pp.336-359.

Tabachnick, B. G. and Fidell, L. S. (2001), Using multivariate statistics $-7^{\text {th }}$ Edition. New York, NY: Pearson.

Tang, Q., Zhao, X. and Liu, S. (2016), "The effect of intrinsic and extrinsic motivations on mobile coupon sharing in social network sites: the role of coupon proneness", Internet Research, Vol. 26 No. 1, pp.101-119.

Thakur, R. (2018), "Customer engagement and online reviews", Journal of Retailing and Consumer Services, Vol. 41, pp.48-59.

Triantafillidou, A. and Siomkos, G. (2018), "The impact of Facebook experience on consumers' behavioural Brand engagement", Journal of Research in Interactive Marketing, Vol.12 No.2, pp.164-192.

Tsai, W. and Men, L. (2013), "Motivations and antecedents of consumer engagement with Brand pages on social networking sites", Journal of Interactive Advertising, Vol. 13 No. 2, pp. 76-87.

van Doorn, J., Lemon, K., Mittal, V., Nass, S., Pick, D., Pirner, P. and Verhoef, P. (2010), "Customer engagement behaviour: Theoretical Foundations and Research Directions", Journal of Service Research, Vol. 13 No. 3, pp. 253-266.

Wang, T., Yeh, R.K.J., Chen, C. and Tsydypov, Z. (2016), "What drives electronic word-ofmouth on social networking sites? Perspectives of social capital and self-determination", Telematics and Informatics, Vol. 33 No. 4, pp.1034-1047.

Wang, Y. and Fesenmaier, D. R. (2003), "Assessing Motivation of Contribution in Online Communities: An Empirical Investigation of an Online Travel Community", Electronic Markets, 
Vol. 13 No.1, pp.33-45.

Wang, X., Lin, X. and Spencer, M.K. (2019), "Exploring the effects of extrinsic motivation on consumer behaviours in social commerce: Revealing consumers' perceptions of social commerce benefits", International Journal of Information Management, Vol. 45, pp.163-175.

We Are Social, (2019), "Digital 2019”, available at: https://p.widencdn.net/kqy7ii/Digital2019-Report-en, (accessed 16 October 2019).

We Are Social, (2020), "Digital 2020 Overview Report”, available at: https://wearesocial.com/blog/2020/04/digital-around-the-world-in-april-2020 (accessed 20 July 2020).

Wirtz, B.W., Piehler, R. and Ullrich, S. (2013), "Determinants of social media website attractiveness", Journal of Electronic Commerce Research, Vol. 14 No. 1, p.11.

Wojnicki, A. and Godes, D. (2011), "Signaling Success: Strategically Positive Word of Mouth", Working paper, Harvard Business School.

Yoo, K. H. and Gretzel, U. (2008), "What Motivates Consumers to Write Online Travel Reviews?", Information Technology \& Tourism, Vol. 10 No. 4, pp.283-295.

YouTube, (2020), 'YouTube at 15: My personal journey and the road ahead", available at: https://blog.youtube/news-and-events/youtube-at-15-my-personal-journey (accessed November 5, 2020). 
Appendix 1. Summary and reliability of measures

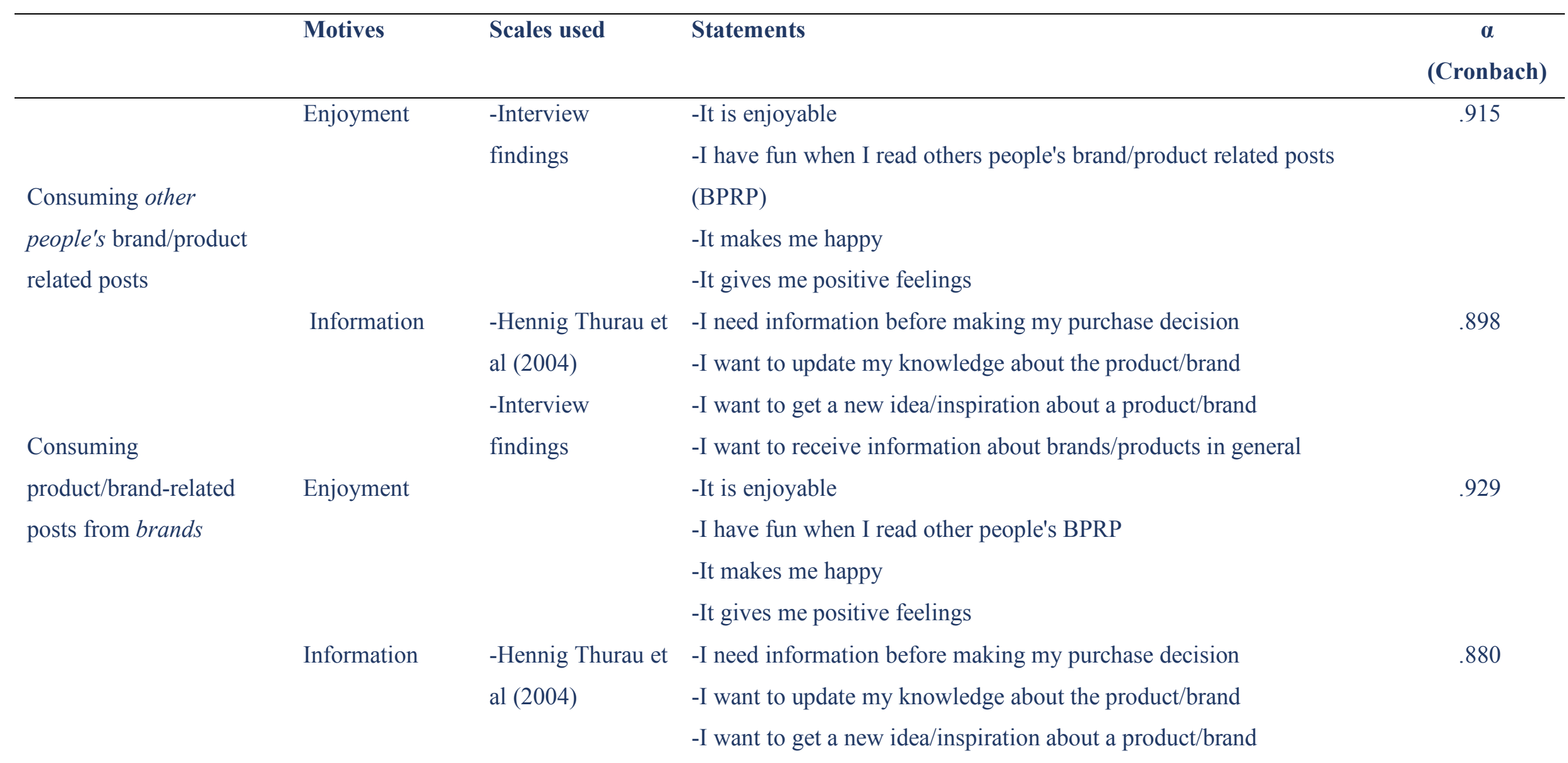


-Interview -I want to receive information about brands/products in general

findings

Contributing other

people's brand/product

Enjoyment

related posts

Communication

with others

Enjoyment

Empowerment

(Positive)

Reward
-It is enjoyable

-I have fun when I participate with other people's brand related posts

-It makes me happy

-It gives me positive feeling

-Hennig Thurau et -I am so delighted with a company and its products that I want to help

$\begin{array}{ll}\text { Helping } & \text { al (2004) } \\ \text { company } & \text {-Interview } \\ & \text { findings }\end{array}$
he company to be successful

-Good companies should be supported

-I want to say thank you as a result of my positive purchase experience

-I can express my enthusiasm

-I have the power to contact a brand on social media easily

-I feel that I can influence others with my experience

-I can publicly make others aware of my purchase experience

-I want to receive a reward (e.g., free product, coupons, etc.)

-I want to engage with the brand because I like it

-I want the brand to communicate with me

-I want to receive points on my loyalty card

-It enables to communicate with others

-It enables me to communicate with my friends

-I feel like I belong to a community when I contribute to the post

-It enables me to communicate with my family

-It is enjoyable 


\section{Contributing}

brand/product related

posts from brands

$\begin{aligned} & \text { Helping } \\ & \text { company }\end{aligned}$
Empowerment

Creating brand/product related posts

Reward
-I have fun when I participate with other people's brand related posts

-It makes me happy

-It gives me positive feeling

-Hennig Thurau et -I am so delighted with a company and its products that I want to help al (2004) the company to be successful

-Interview

-Good companies should be supported

findings

-I want to say thank you as a result of my positive purchase experience

-I can express my enthusiasm

-I have the power to contact a brand on social media easily

-I feel that I can influence others with my experience

-I can publicly make others aware of my purchase experience

-I want to receive a reward (e.g., free product, coupons, etc.)

-I want to engage with the brand because I like it

-I want the brand to communicate with me

-I want to receive points on my loyalty card
Expressing

negative feeling
-Hennig Thurau et -The company harm me, and now I want to harm them

al (2004)

-I want to vent my frustration

-Interview

-I want to express my anger

findings

I want them to improve their/product

I want to warn others of bad products/brands
I want to save others from having the same negative experience as me I want to others to buy the right product 
Empowerment

(Negative)

Enjoyment

Empowerment

Self-identity

Helping
I can publicly embarrass the company

I want the wider public to know what my experience was like

I have the power to make contact with brands easily on social media

I can publicly make others ware of my negative purchase experience

-Hennig Thurau et I want to others get benefits form the product

al (2004) I want to help others who are looking for advice

-Interview I want to share my positive experience

findings

I want to receive a reward (e.g., free product, coupons etc.)

I want the brand to communicate with me (e.g., Tweet, comment etc.)

I want to receive points on my loyalty card

-Hennig Thurau et I am so delighted with a company and its product that I want to help the

al (2004)

company to be successful

-Interview

Good companies should be supported

findings

The company needs support

I want to say thank you as result of my positive purchase experience

I can express my enthusiasm

I have the power to make contact with brand easily on social media

I feel that I can influence other with my opinion

I can publicly make others aware of my purchase experience

I can present myself and my purchase experience

I want to show my expertise about the product and/or product 
I can express my personality

I want to receive 'likes, retweet, favourite' from others

It enables me to communicate with others

Communicate

with others
It enables me to communicate with others

I feel like I belong to community when I post

It enables me to communicate with my family 